\title{
Synthesis and Sintering Behavior of $\mathrm{Zr}_{2} \mathrm{WP}_{2} \mathrm{O}_{12}$ Ceramics
}

\author{
Yong-Hyeon Kim, Nam-Ok Kim, and Sang-Jin Lee ${ }^{\dagger}$ \\ Department of Advanced Materials Science and Engineering, Mokpo National University, Muan 534-729, Korea \\ (Received July 16, 2012; Revised August 26, 2012; Accepted August 27, 2012)
}

\author{
$\mathrm{Zr}_{2} \mathrm{WP}_{2} \mathrm{O}_{12}$ 세라믹스의 합성과 소결거동 연구 \\ 김용현 · 김남옥 · 이상진 ${ }^{\dagger}$ \\ 국립목포대학교 신소재공학과 \\ (2012년 7월 16일 접수 ; 2012년 8월 26일 수정 ; 2012년 8월 27일 채택)
}

\begin{abstract}
$\mathrm{Zr}_{2} \mathrm{WP}_{2} \mathrm{O}_{12}$ powder, which has a negative thermal expansion coefficient, was synthesized by a solid-state reaction with $\mathrm{ZrO}_{2}, \mathrm{WO}_{3}$ and $\mathrm{NH}_{4} \mathrm{H}_{2} \mathrm{PO}_{4}$ as the starting materials. The synthesis behavior was dependent on the solvent media used in the wet mixing process. The $\mathrm{Zr}_{2} \mathrm{WP}_{2} \mathrm{O}_{12}$ powder prepared with a solvent consisting of D. I. water was fully crystallized at $1200^{\circ} \mathrm{C}$, showing a sub-micron particle size. According to the results obtained from a thermal analysis, a $\mathrm{ZrP}_{2} \mathrm{O}_{7}$ was synthesized at a low temperature of $310^{\circ} \mathrm{C}$, after which it was reacted with $\mathrm{WO}_{3}$ at $1200^{\circ} \mathrm{C}$. A new sintering additive, $\mathrm{Al}(\mathrm{OH})_{3}$, was applied for the densification of the $\mathrm{Zr}_{2} \mathrm{WP}_{2} \mathrm{O}_{12}$ powders. The cold isostatically pressed samples were densified with $1 \mathrm{wt} \% \mathrm{Al}(\mathrm{OH})_{3}$ additive or more at $1200^{\circ} \mathrm{C}$ for $4 \mathrm{~h}$. The main densification mechanism was liquid-phase sintering due to the liquid which resulted from the reaction with amorphous or unstable $\mathrm{Al}_{2} \mathrm{O}_{3}$ and $\mathrm{WO}_{3}$. The densified $\mathrm{Zr}_{2} \mathrm{WP}_{2} \mathrm{O}_{12}$ ceramics showed a relative density of $90 \%$ and a negative thermal expansion coefficient of $-3.4 \times 10^{-6} \rho^{\circ} \mathrm{C}$. When using $\alpha-\mathrm{Al}_{2} \mathrm{O}_{3}$ as the sintering agent, densification was not observed at $1200^{\circ} \mathrm{C}$.
\end{abstract}

Key words : $\mathrm{Zr}_{2} \mathrm{WP}_{2} \mathrm{O}_{12}$, Thermal expansion, Sintering, $\mathrm{Al}_{2} \mathrm{O}_{3}, \mathrm{Al}(\mathrm{OH})_{3}$, Microstructure

\section{1. 서 론}

영(0)에 가까운 열팽창계수를 갖는 세라믹 재료들은 급 격한 가열이나 냉각에 의한 열충격에 매우 높은 저항성 을 가진다. 이처럼 열팽창계수가 낮은 세라믹 재료들은 열적 내구성을 필요로 하는 세라믹 부품에 필수적으로 사 용된다. 주로 알려진 저열팽창 세라믹 재료로는 $\mathrm{MAS}$ $\left(\mathrm{MgO}, \mathrm{Al}_{2} \mathrm{O}_{3}, \mathrm{SiO}_{2}\right)$ 계와 $\mathrm{LAS}\left(\mathrm{Li}_{2} \mathrm{O}, \mathrm{Al}_{2} \mathrm{O}_{3}, \mathrm{SiO}_{2}\right)$ 계 조 성을 갖는 재료들이 있으며, 이들은 내열 충격성을 요구 하는 부품에 널리 사용되고 있다. ${ }^{1,2)}$

세라믹 제조 공정에서 음의 열팽창계수를 갖는 세라믹 재료들은, 재료의 특성상 한가지 조성으로 사용되기 보다 는, 혼합 성분으로 사용되어 재료의 열팽창을 낮추는데 활용된다. $\beta$-eucryptite $\left(\mathrm{Li}_{2} \mathrm{O} \cdot \mathrm{Al}_{2} \mathrm{O}_{3} \cdot 2-\mathrm{SiO}_{2}\right)$ 와 $(\mathrm{ZrO})_{2} \mathrm{P}_{2} \mathrm{O}_{7}$ 세라믹스는 이방성 변형에서 발생되는 음의 열팽창계수 (NTE : negative thermal expansion)를 가지며, $\mathrm{ZrW}_{2} \mathrm{O}_{8}$ 와 $\mathrm{HfW}_{2} \mathrm{O}_{8}$ 는 입방체 결정 구조를 가지는 NTE 재료로 알

\footnotetext{
${ }^{\dagger}$ Corresponding author : Sang-Jin Lee

E-mail : lee@mokpo.ac.kr

Tel : +82-61-450-2493 Fax : +82-61-450-2498
}

려져 있고, 최근에는 $\mathrm{Zr}_{2} \mathrm{WP}_{2} \mathrm{O}_{12}$ 세라믹스가 새로운 $\mathrm{NTE}$ 재료로써 연구되고 있다. ${ }^{3)} \mathrm{ZrW}_{2} \mathrm{O}_{8}$ 계의 NTE 재료로는 $\mathrm{Cu}$ / $\mathrm{ZrW}_{2} \mathrm{O}_{8}{ }^{4)} \mathrm{ZrO}_{2} / \mathrm{ZrW}_{2} \mathrm{O}_{8},{ }^{5-7)}$ epoxy/ $\mathrm{ZrW}_{2} \mathrm{O}_{8}{ }^{8},{ }^{8} \mathrm{SiO}_{2} / \mathrm{ZrW}_{2} \mathrm{O}_{8}{ }^{9}$ ) $\mathrm{Al} / \mathrm{ZrW}_{2} \mathrm{O}_{8}{ }^{10)}$ 등이 있으나, 이들의 열팽창 거동은 매우 복 잡하여 정확한 고찰이 이루어지지 않고 있다.

최근 레이저에 의해 접합이 가능한 OLED용 무기소재 개발에 있어, 열팽창계수의 조절을 위하여 $\mathrm{ZrW}_{2} \mathrm{O}_{8}$ 계에 산화인 $\left(\mathrm{P}_{2} \mathrm{O}_{3}\right)$ 이 포함된 $\mathrm{Zr}_{2} \mathrm{WP}_{2} \mathrm{O}_{12}$ 세라믹 분말의 활용이 연구되고 있다. ${ }^{11,12)} \mathrm{Zr}_{2} \mathrm{WP}_{2} \mathrm{O}_{12}$ 구조는 팔면체인 $\mathrm{ZrO}_{6}$ 가 $\mathrm{WO}_{4}, \mathrm{PO}_{4}$ 사면체 모서리를 서로 공유하고 있으며, 이방 성 열팽창에 의하여 NTE를 보인다고 추론하고 있다. ${ }^{13)}$ $\mathrm{Zr}_{2} \mathrm{WP}_{2} \mathrm{O}_{12}$ 재료에 대한 연구는 분말의 합성뿐만 아니라 소결에 대한 연구도 진행되고 있다. 특히 $\mathrm{Zr}_{2} \mathrm{WP}_{2} \mathrm{O}_{12}$ 세라 믹 분말은 소결온도 범위가 매우 좁은 $\mathrm{MAS}$ 계의 cordierite $\left(2 \mathrm{MgO} \cdot 2 \mathrm{Al}_{2} \mathrm{O}_{3} \cdot 5 \mathrm{SiO}_{2}\right)$ 와 같이 성형 후 소결이 쉽지 않 은 재료이다. $\mathrm{Zr}_{2} \mathrm{WP}_{2} \mathrm{O}_{12}$ 의 치밀화를 위하여 소결조제 첨 가에 의한 액상소결 기구가 제시되고 있으며, $\mathrm{MgO}$ 를 소 결조제로 사용하여 상대밀도 $90 \%$ 이상의 소결체 제조에 대한 연구가 진행되었다. ${ }^{3)}$ 제조된 $\mathrm{Zr}_{2} \mathrm{WP}_{2} \mathrm{O}_{12}$ 성형체의 경 우 $60 \%$ 의 상대밀도를 보였으나, $0.5 \mathrm{wt} \%$ 의 $\mathrm{MgO}$ 를 소결조 제로 첨가한 후 $95 \%$ 의 상대밀도를 얻었으며, $-3.4 \times 10^{-6} \% \mathrm{C}$ 
의 음의 열팽창계수를 갖는 $\mathrm{Zr}_{2} \mathrm{WP}_{2} \mathrm{O}_{12}$ 세라믹스를 제조 하였다. 제조된 세라믹스의 영률, 포아슨비, 3점 굽힘강도, 경도, 파괴인성은 각각 $74 \mathrm{GPa}, 0.25,113 \pm 13 \mathrm{MPa}, 4.4$ $\mathrm{GPa}, 2.3 \mathrm{MPa} \cdot \mathrm{m}^{1 / 2}$ 의 값을 갖는다고 보고하였다. 또 다 른 연구로, 합성된 $\mathrm{ZrW}_{2} \mathrm{O}_{8}$ 에 $\mathrm{P}_{2} \mathrm{O}_{5}$ 를 첨가하여 $\mathrm{NTE}$ 를 갖 는 $\mathrm{ZrW}_{2} \mathrm{O}_{8} / \mathrm{Zr}_{2} \mathrm{WP}_{2} \mathrm{O}_{12}$ 복합재료가 제조되었다. ${ }^{14)} 20 \mathrm{~mol} \%$ 의 $\mathrm{P}_{2} \mathrm{O}_{5}$ 함량에서 $\mathrm{Zr}_{2} \mathrm{WP}_{2} \mathrm{O}_{12}$ 가 주 결정상을 이루고 $\mathrm{ZrW}_{2} \mathrm{O}_{8}$ 가 일부 존재하는 복합체가 제조되어졌고, 이러한 복합체는 $90 \%$ 의 상대밀도를 보였으며, $-4.0 \times 10^{-6} /{ }^{\circ} \mathrm{C}$ 의 음 의 열팽창계수를 나타내었다.

본 연구에서는 고상법을 통한 $\mathrm{Zr}_{2} \mathrm{WP}_{2} \mathrm{O}_{12}$ 분말합성과 새 로운 소결조제인 $\mathrm{Al}_{2} \mathrm{O}_{3}$ 와 $\mathrm{Al}(\mathrm{OH})_{3}$ 를 적용하여 상압소결 을 통한 소결거동을 고찰하였다. 분말합성에서는 습식에 의한 원료혼합 시 혼합용매를 달리하였을 때 분말의 합 성에 미치는 영향을 고찰하였으며, 새로운 소결조제에 적 용에 대한 결과는 $\mathrm{MgO}$ 를 소결조제로 첨가하여 얻어진 결과와 비교, 고찰하였다.

\section{2. 실험방법}

\section{1. $\mathrm{Zr}_{2} \mathrm{WP}_{2} \mathrm{O}_{12}$ 분말 합성}

$\mathrm{Zr}_{2} \mathrm{WP}_{2} \mathrm{O}_{12}$ 분말 제조는 출발원료로 $\mathrm{ZrO}_{2}$ (TZ-0; Tosoh Corp., Japan), $\mathrm{WO}_{3}$ (99.5\%, Wako Pure Chemical Industries Ltd., Japan)와 $\mathrm{NH}_{4} \mathrm{H}_{2} \mathrm{PO}_{4}$ (high purity, Wako Pure Chemical Industries Ltd., Japan)을 사용하였으며, 이들을 2:1:2의 몰 비율로 혼합하였다. 분말의 습식혼합을 위해 사용된 용매 는 증류수, 에틸 알코올 그리고 에틸 알코올과 증류수의 혼합용액를 각각 사용하여 합성거동에 미치는 영향을 알 아보았다. 에틸 알코올과 증류수 혼합용액의 경우는 $\mathrm{NH}_{4} \mathrm{H}_{2} \mathrm{PO}_{4}$ 가 물에 잘 녹는 성질을 이용하여 에틸 알코올 과 $\mathrm{ZrO}_{2}$ 와 $\mathrm{WO}_{3}$ 이 혼재된 슬러리에 증류수로 녹인 $\mathrm{NH}_{4} \mathrm{H}_{2} \mathrm{PO}_{4}$ 용액을 첨가하여 혼합하였다. 혼합은 교반기 를 통하여 수시간 동안 진행하였다. 각각의 건조된 혼합 물은 합성을 위하여 공기분위기, $1200^{\circ} \mathrm{C}$ 에서 4 시간 동안 열처리하였다. 승온속도는 분당 $5^{\circ} \mathrm{C}$ 로 실험하였다. 열처리 된 분말은 X선 회절분석기 (Rigaku 2200, Tokyo, Japan)를 이용하여 합성된 결정상을 확인하였다. 또한 열분석기 (TGA/ DSC 1 Star system, Mettler Toldedo, Switzerland)를 이용하 여 합성거동을 고찰하였으며, 분석은 공기분위기에서 $1200^{\circ} \mathrm{C}$ 까지 분당 $10^{\circ} \mathrm{C}$ 의 가열속도로 진행하였다. 합성 된 분말의 형상은 주사전자현미경 (SEM, 3500N/Hitachi, Japan)을 사용하여 관찰하였고, 입도분석은 레이저입도 분석기 (Mastersizer S/Malvern Instruments Ltd.)를 이 용하였다. 입도분석을 위하여 용액 내의 분말은 초음파 를 이용하여 5 분간 처리하여 응집을 제거한 후 측정하 였다.

\section{2. $\mathrm{Zr}_{2} \mathrm{WP}_{2} \mathrm{O}_{12}$ 소결체 제조}

합성된 $\mathrm{Zr}_{2} \mathrm{WP}_{2} \mathrm{O}_{12}$ 분말의 소결을 위하여 $\mathrm{Al}_{2} \mathrm{O}_{3}(99.6 \%$, $\mathrm{KC}$ Corp., Korea)와 $\mathrm{Al}(\mathrm{OH})_{3}(99.6 \%$, KC Corp., Korea) 를 각각 소결조제로 사용하여 $0.5 \sim 5 \mathrm{wt} \%$ 까지 점진적으로 양을 늘려 첨가하였다. 소결조제 혼합 후 에틸 알코올을 용매로 24 시간 동안 습식 볼밀링 공정을 거친 후 건조시 켰다. 건조된 분말은 일축가압 방법으로 $4 \mathrm{MPa}$ 압력하에 서 1 분 동안 유지하여 디스크 타입의 성형체를 제조하였 다. 일축 가압된 시편의 일부는 $150 \mathrm{MPa}$ 의 압력으로 3 분 간 냉간 등압성형을 실시하여, 일축 가압된 시편과 소결 거동을 비교, 고찰하였다. 소결은 공기분위기, $1200^{\circ} \mathrm{C}$ 에서 4시간 동안 유지하여 소결하였다. ${ }^{3)}$ 소결 시 승온속도는 분당 $5^{\circ} \mathrm{C}$ 의 가열속도로 열처리하였다. 소결된 샘플들은 버어니어캘리퍼스를 이용하여 5 번 이상 측정한 지름과 높 이의 평균값과 측정된 질량을 데이터로 하여 수축률과 소 결밀도를 각각 계산하였다. 소결밀도는 $\mathrm{Zr}_{2} \mathrm{WP}_{2} \mathrm{O}_{12}$ 의 이 론밀도인 $3.99 \mathrm{~g} / \mathrm{cm}^{3}$ 에 대하여 ${ }^{11)}$ 상대밀도로 나타내었다. 소결된 샘플의 미세구조는 시편의 표면을 주사전자현미 경 (SEM, 3500N/Hitachi, Japan)을 사용하여 관찰하였다. 제조된 샘플의 열팽창계수는 Dilatometer (DIL 402C, $\mathrm{Netzsch}$ )를 이용하여 $30 \sim 600^{\circ} \mathrm{C}$ 의 온도범위에서 분당 $10^{\circ} \mathrm{C}$ 의 가열 속도로 측정하였다.

\section{3. 결과 및 고찰}

\section{1. $\mathrm{Zr}_{2} \mathrm{WP}_{2} \mathrm{O}_{12}$ 합성}

$\mathrm{ZrO}_{2}-\mathrm{WO}_{3}-\mathrm{NH}_{4} \mathrm{H}_{2} \mathrm{PO}_{4}$ 혼합물 제조 시, 혼합용매를 달리하 여 합성한 분말의 XRD 분석결과를 Fig. 1에 나타내었다. 증류수를 혼합용매로 사용한 경우 잘 발달된 $\mathrm{Zr}_{2} \mathrm{WP}_{2} \mathrm{O}_{12}$ 결

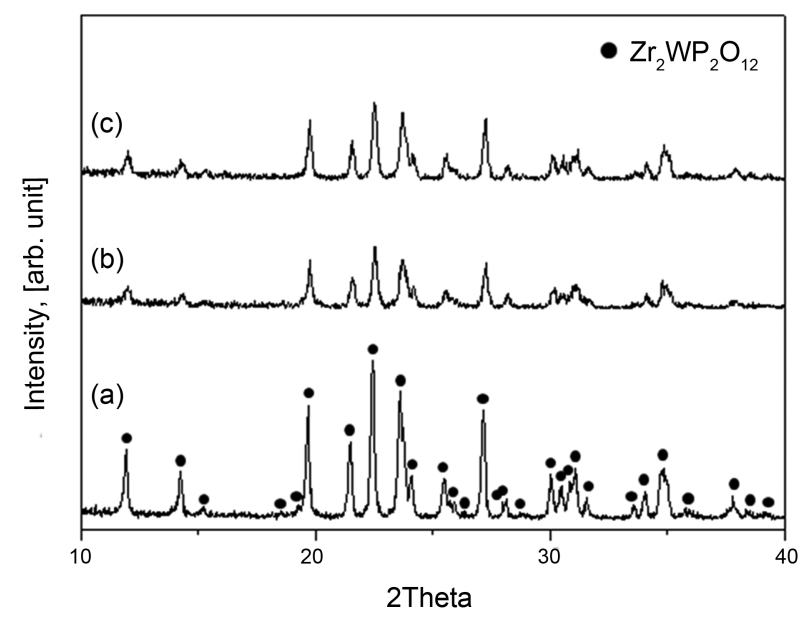

Fig. 1. XRD patterns of synthesized $\mathrm{Zr}_{2} \mathrm{WP}_{2} \mathrm{O}_{12}$ powders prepared from different mixing processing solvents: (a) D. I. water, (b) ethyl alcohol, and (c) ethyl alcohol+D. I. water. 

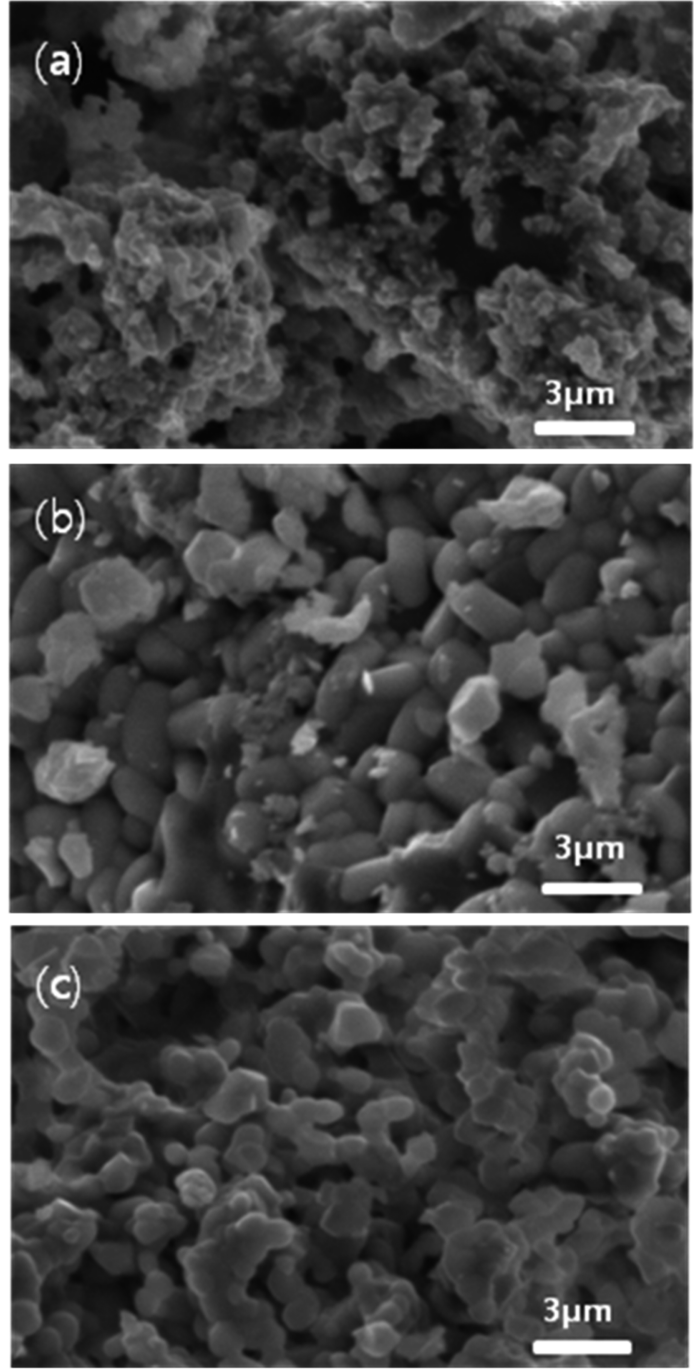

Fig. 2. SEM micrographs of synthesized $\mathrm{Zr}_{2} \mathrm{WP}_{2} \mathrm{O}_{12}$ powders prepared from different mixing processing solvents: (a) D. I. water, (b) ethyl alcohol, and (c) ethyl alcohol + D. I. water.

정상이 관찰되는 반면에, 에틸 알콜 혹은 에틸 알코올과 증 류수 혼합용액을 사용한 경우는 동일한 결정상을 보이지 만 상대적으로 결정성이 낮은 결과를 보여주고 있다. 합 성된 분말의 미세구조 관찰결과는 Fig. 2에 나타내었다. 증류수를 이용하여 제조한 분말은, 응집된 분말형태를 보 이며 sub-micron 크기의 상대적으로 작은 입자크기를 보 였다. 반면에 에틸 알코올이 적용된 분말의 경우는 $1 \mu \mathrm{m}$ 이 상의 입자크기를 보였다. 모든 분말에서 부분적으로 presintering 현상이 관찰되는데, 이것은 비교적 높은 합성온 도 때문으로 판단된다. 예비실험에 의하면 $1200^{\circ} \mathrm{C}$ 미만에 서는 $\mathrm{Zr}_{2} \mathrm{WP}_{2} \mathrm{O}_{12}$ 외에 미반응 상들이 관찰되었다. 이상의 결과에서 보면, 증류수를 용매로 사용하였을 때 우수한 합성거동과 미세한 분말크기를 보이게 되는데, 이것은 $\mathrm{NH}_{4} \mathrm{H}_{2} \mathrm{PO}_{4}$ 가 물에 용해되는 성질에 의하여 보다 균질한

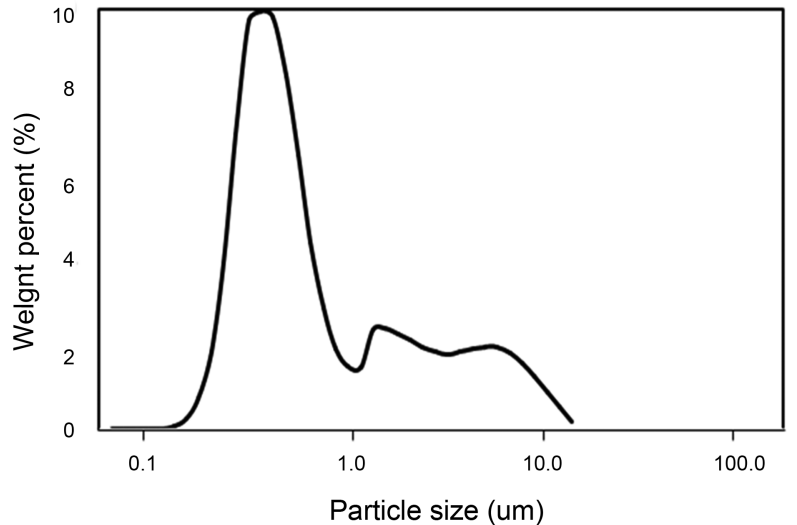

Fig. 3. Particle size distribution of synthesized $\mathrm{Zr}_{2} W_{2} \mathrm{O}_{12}$ powder prepared from D. I. water solvent.

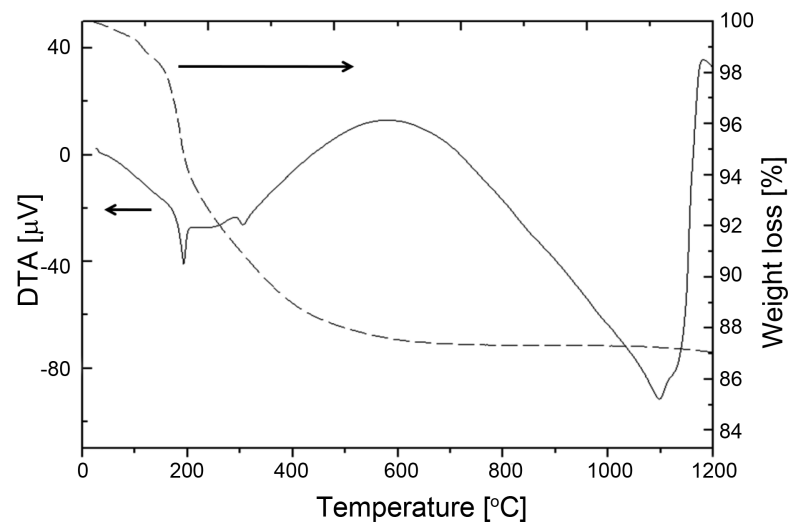

Fig. 4. DTA-TG curves of $\mathrm{Zr}_{2} \mathrm{WP}_{2} \mathrm{O}_{12}$ precursor prepared from D. I. water solvent.

혼합체가 가능하기 때문이라 판단된다. 반면에 에틸 알코 올에는 $\mathrm{NH}_{4} \mathrm{H}_{2} \mathrm{PO}_{4}$ 가 용해되지 않아, 상대적으로 불균질 한 혼합과 고상반응에 의하여 낮은 결정성과 큰 입자 크 기를 보였다고 판단된다. Fig. 3 은 증류수를 사용하여 제 조된 $\mathrm{Zr}_{2} \mathrm{WP}_{2} \mathrm{O}_{12}$ 분말의 입도분포를 보여준다. 입자 평균 크기는 약 $0.7 \mu \mathrm{m}$ 를 보이며, $1 \mu \mathrm{m}$ 이상의 입자도 관찰되 는데, 이것은 일부 응집된 입자로 인한 결과라 여겨진다.

Fig. 4는 증류수를 용매로 사용한 $\mathrm{Zr}_{2} \mathrm{WP}_{2} \mathrm{O}_{12}$ 전구체 혼 합물의 열분석 결과를 보여준다. 가장먼저 $200^{\circ} \mathrm{C}$ 에서 무 게감소와 함께 흡열반응을 보여주는데, 이것은 $\mathrm{NH}_{4} \mathrm{H}_{2} \mathrm{PO}_{4}$ 의 분해에 의한 결과라 생각된다. $310^{\circ} \mathrm{C}$ 부근에서 나타나 는 작은 발열반응은 $\mathrm{ZrO}_{2}$ 와 $\mathrm{P}_{2} \mathrm{O}_{5}$ 가 반응하여 $\mathrm{ZrP}_{2} \mathrm{O}_{7}$ 를 생성하는 반응과 관계가 있다고 판단되며, 이러한 반응은 Isobe 등 ${ }^{3)}$ 에 의한 연구결과와 잘 일치한다. 비교적 낮은 온도에서 합성된 $\mathrm{ZrP}_{2} \mathrm{O}_{7}$ 는 $1100^{\circ} \mathrm{C}$ 까지 별다른 반응을 보 이지 않으며, $1100^{\circ} \mathrm{C}$ 이상의 온도에서 $\mathrm{ZrO}_{2}$ 및 $\mathrm{WO}_{3}$ 와 반 응하여 $\mathrm{Zr}_{2} \mathrm{WP}_{2} \mathrm{O}_{12}$ 가 합성된다고 보고하고 있다. 본 열분 석 결과에서도 $1100^{\circ} \mathrm{C}$ 이후에 보여지는 큰 발열피크는 $\mathrm{Zr}_{2} \mathrm{WP}_{2} \mathrm{O}_{12}$ 의 생성에 의한 발열반응이라 판단된다. 열분 
석 결과 총 $13 \%$ 의 중량감소 보이며, $\mathrm{Zr}_{2} \mathrm{WP}_{2} \mathrm{O}_{12}$ 합성의 주요반응이 $1100^{\circ} \mathrm{C} \sim 1200^{\circ} \mathrm{C}$ 사이에서 일어남을 알 수 있 다. 따라서 합성 시 충분한 반응을 위하여 $1200^{\circ} \mathrm{C}$ 에서 장 시간 유지시키는 것이 유리할 것으로 판단되며, 본 연구 에서도 이 같은 이유로 $1200^{\circ} \mathrm{C}$ 에서 4시간 동안 유지하였다.

\section{2. $\mathrm{Zr}_{2} \mathrm{WP}_{2} \mathrm{O}_{12}$ 소결특성}

$\mathrm{Al}_{2} \mathrm{O}_{3}$ 와 $\mathrm{Al}(\mathrm{OH})_{3}$ 를 소결조제로 첨가한 $\mathrm{Zr}_{2} \mathrm{WP}_{2} \mathrm{O}_{12}$ 의 소 결거동은 소결조제 첨가량과 성형방법을 달리하여 고찰 하였다. 본 실험에서는 증류수를 사용하여 $1200^{\circ} \mathrm{C}$ 에서 합 성한 $\mathrm{Zr}_{2} \mathrm{WP}_{2} \mathrm{O}_{12}$ 분말을 사용하였다. $\mathrm{Al}_{2} \mathrm{O}_{3}$ 를 첨가한 경우, 첨가량과 성형방법에 관계없이 $1200^{\circ} \mathrm{C}$ 열처리 후 전혀 밀 도의 증가가 관찰되지 않았다. 이것은 소결조제를 첨가하 지 않은 $\mathrm{Zr}_{2} \mathrm{WP}_{2} \mathrm{O}_{12}$ 의 소결거동과 거의 비슷한 결과이며, 일부 시편에서는 약간의 부피팽창이 관찰되었다. 그러나, $\mathrm{Al}(\mathrm{OH})_{3}$ 를 첨가한 경우는 밀도의 증가를 보였으며, 첨가 량 및 성형 방법에 따른 치밀화 거동을 Fig. 5에 나타내 었다. 낮은 압력에서 실시된 일축가압 성형체와 이보다 높은 압력에서의 냉간등압 성형체의 경우, 각각의 성형밀 도는 $56.1 \%$ 와 $61.2 \%$ 의 상대밀도를 보였다. 모든 샘플은 $\mathrm{Al}(\mathrm{OH})_{3}$ 첨가량의 증가에 따라 소결밀도가 증가하는 경 향을 보였으며, 첨가량 $4 \mathrm{wt} \%$ 부터는 더 이상의 밀도증가 가 관찰되지 않았다. 특히 냉간등압 성형체의 경우 일축 가압 성형체에 비하여, $1 \mathrm{wt} \%$ 의 첨가량에도 $80 \%$ 이상의 상대밀도를 보이며, $\mathrm{MgO}$ 를 첨가제로 사용한 Isobe 등 ${ }^{3)}$ 에 의한 연구결과와 유사한 소결거동을 나타내었다. 이러한 결과로부터 $\mathrm{Al}(\mathrm{OH})_{3}$ 첨가 시, $\mathrm{MgO}$ 와 같은 액상소결이 진 행되어 치밀화가 발현되었다고 볼 수 있으며, $\mathrm{Al}_{2} \mathrm{O}_{3}$ 첨가 시는 액상의 생성이 부족하여 원활한 액상소결이 이루어 지지 않은 것으로 판단된다. 이러한 고찰은 $\mathrm{MgO}$ 와 $\mathrm{WO}_{3}$ 그리고 $\mathrm{Al}_{2} \mathrm{O}_{3}$ 와 $\mathrm{WO}_{3}$ 간의 상평형도에서 추측이 가능한데,

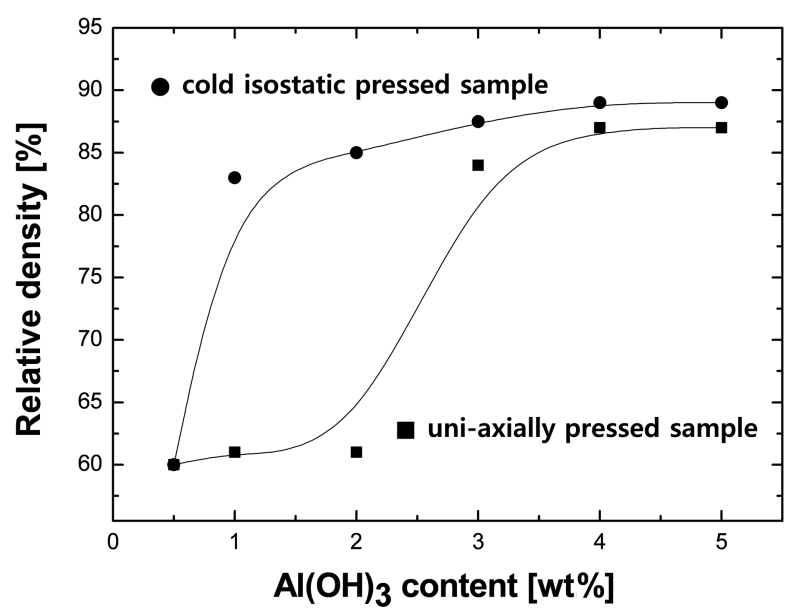

Fig. 5. Relative densities of sintered $\mathrm{Zr}_{2} \mathrm{WP}_{2} \mathrm{O}_{12}$ ceramics at $1200^{\circ} \mathrm{C}$ according to $\mathrm{Al}(\mathrm{OH})_{3}$ content and forming method.
$\mathrm{MgO}$ 의 경우는 $\mathrm{WO}_{3}$ 와 반응하여 $1120^{\circ} \mathrm{C}$ 에서 액상이 생성 된다. ${ }^{15)}$ 반면에 $\mathrm{Al}_{2} \mathrm{O}_{3}$ 는 $1190^{\circ} \mathrm{C}$ 부터 $\mathrm{WO}_{3}$ 와의 반응에 의 하여 액상 형성이 시작된다. ${ }^{16)}$ 이 같은 상평형도 결과를 참조해 볼 때, $\mathrm{MgO}$ 의 경우는 $\mathrm{Zr}_{2} \mathrm{WP}_{2} \mathrm{O}_{12}$ 합성 시 미 반 응된 소량의 $\mathrm{WO}_{3}$ 와 반응하여 액상형성이 발현되어 $1200^{\circ} \mathrm{C}$ 에서 장시간 열처리함으로써 입자의 재배열 등 액상소결 이 진전되어 치밀화가 진행되는 것으로 판단된다. 반면에 $\mathrm{Al}_{2} \mathrm{O}_{3}$ 는 $\mathrm{WO}_{3}$ 와의 액상 형성 온도가 거의 $1200^{\circ} \mathrm{C}$ 에 접근 되어 있어, 원활한 액상소결이 발현되지 못한 것으로 생 각된다. $\mathrm{Al}(\mathrm{OH})_{3}$ 의 경우는 $\mathrm{WO}_{3}$ 와의 상평형도가 존재하 지 않으나, 열분해에 의해 남게 되는 $\mathrm{Al}$ 이 안정된 구조를 보이는 $\alpha-\mathrm{Al}_{2} \mathrm{O}_{3}$ 로 결정화되기 전에 미 반응된 $\mathrm{WO}_{3}$ 와 반 응을 일으켜 $1190^{\circ} \mathrm{C}$ 보다 낮은 온도에서 액상을 형성하 여 액상소결이 진행되었다고 추측된다. 이러한 액상소결 은 Fig. 5에서 보듯이 냉간등압에 의하여 성형밀도가 증 가된 시편에서는 액상에 의한 입자의 재배열이 원활히 일 어나 적은 양의 액상에서도 치밀화가 진행되었다고 생각 된다.

첨가된 소결조제에 따라 최종 결정상에 미치는 영향을 조사하기 위해 $1200^{\circ} \mathrm{C}$ 에서 소결 된 샘플의 $\mathrm{XRD}$ 패턴을 Fig. 6에 나타내었다. $\mathrm{Al}_{2} \mathrm{O}_{3}$ 와 $\mathrm{Al}(\mathrm{OH})_{3}$ 를 각각 $3 \mathrm{wt} \%$ 를 넣어 열처리 한 결과 모두 잘 발달된 $\mathrm{Zr}_{2} \mathrm{WP}_{2} \mathrm{O}_{12}$ 결정상 이 관찰되었다. 즉, 새로이 적용된 소결조제도 $\mathrm{MgO}$ 와 같 이 소결분말인 $\mathrm{Zr}_{2} \mathrm{WP}_{2} \mathrm{O}_{12}$ 의 결정성에 특별한 영향을 주 지 않음을 알 수 있다. Fig. 7 에는 $1200^{\circ} \mathrm{C}$ 에서 소결된 샘 플의 표면 미세구조를 나타내었다. 모두 $3 \mathrm{wt} \%$ 의 첨가제 를 적용했을 경우의 $\mathrm{Zr}_{2} \mathrm{WP}_{2} \mathrm{O}_{12}$ 미세구조를 보여주고 있 다. $\mathrm{Al}_{2} \mathrm{O}_{3}$ 를 첨가한 경우는 부분적으로 거대 입자가 관찰 되기는 하지만 전체적으로 입성장이 거의 관찰되지 않고, 많은 기공이 존재함을 볼 수 있다. $\mathrm{Al}(\mathrm{OH})_{3}$ 를 첨가하여 일축가압 성형한 경우는 확연한 입성장과 함께 치밀화된

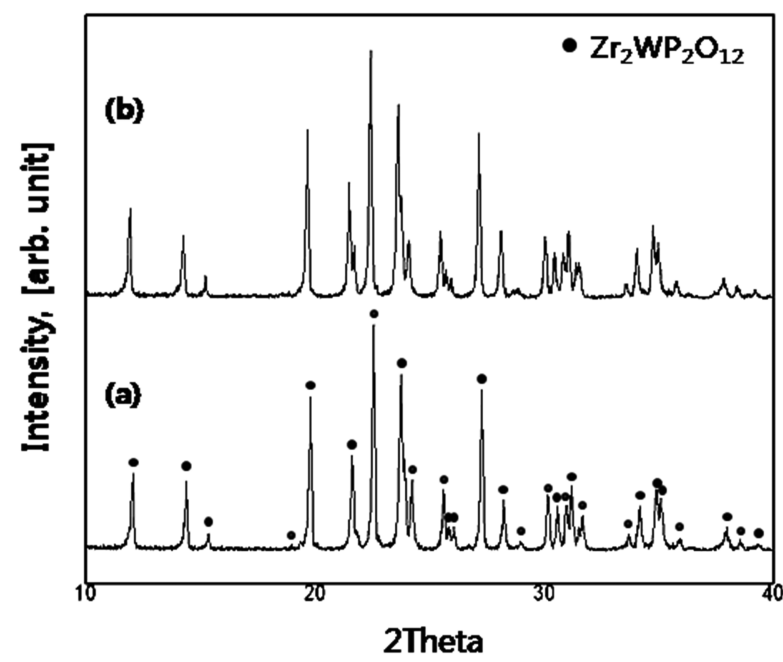

Fig. 6. $\mathrm{XRD}$ patterns of sintered samples added (a) $3 \mathrm{wt} \%$ $\mathrm{Al}_{2} \mathrm{O}_{3}$ and (b) $3 \mathrm{wt} \% \mathrm{Al}(\mathrm{OH})_{3}$. 

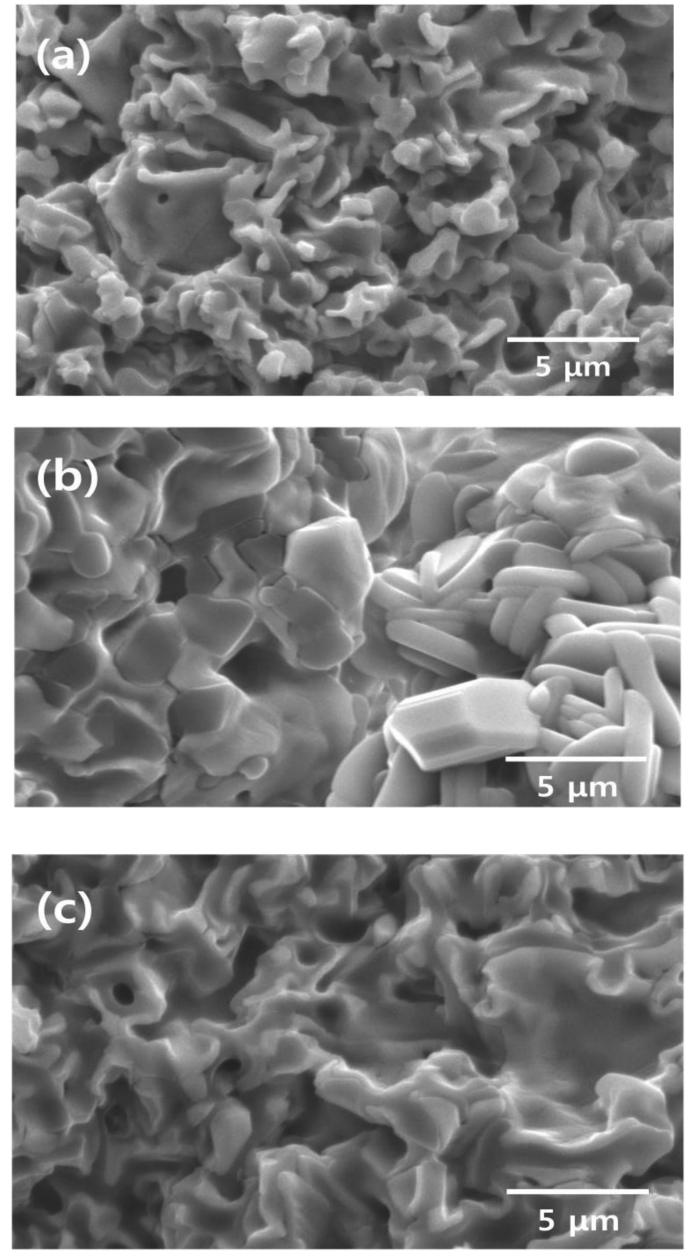

Fig. 7. $\mathrm{SEM}$ micrographs of $\mathrm{Zr}_{2} \mathrm{WP}_{2} \mathrm{O}_{12}$ ceramics (surface) sintered at $1200^{\circ} \mathrm{C}$ for $4 \mathrm{~h}$ with (a) $3 \mathrm{wt} \% \mathrm{Al}_{2} \mathrm{O}_{3}$, (b) $3 \mathrm{wt} \% \mathrm{Al}(\mathrm{OH})_{3}$ (uni-aixally pressed sample), and (c) $3 \mathrm{wt} \% \mathrm{Al}(\mathrm{OH})_{3}$ (cold isostatic pressed sample).

미세구조를 보이지만, 부분적으로 거대 기공이 존재함을 확인 할 수 있었다. $\mathrm{Al}(\mathrm{OH})_{3}$ 를 첨가하여 냉간등압 성형한 경우도 역시 입성장의 발현을 볼 수 있으며, 액상의 존재 를 확인할 수 있는 미세구조를 보이고 있다.

Fig. 8은 $3 \mathrm{wt} \%$ 의 $\mathrm{Al}(\mathrm{OH})_{3}$ 를 첨가하여 냉간등압 성형 후 소결하여 얻은 시편의 열팽창거동을 보여주고 있다. 약 $200^{\circ} \mathrm{C}$ 까지는 확연한 음의 열팽창 거동을 보이고 있으 며, 이후로는 거의 영 $(0)$ 에 가까운 열팽창 거동을 보였다. 분석온도인 $600^{\circ} \mathrm{C}$ 까지 계산된 열팽창계수는 $-3.4 \times 10^{-6} \% \mathrm{C}$ 로서 $\mathrm{MgO}$ 를 소결조제로 사용한 $\mathrm{Zr}_{2} \mathrm{WP}_{2} \mathrm{O}_{12}$ 의 열팽창계 수와 동일한 수치를 나타내었다.

\section{4. 결 론}

증류수를 습식혼합 용매로 사용하여 합성한 $\mathrm{Zr}_{2} \mathrm{WP}_{2} \mathrm{O}_{12}$ 분말은 결정성이 뛰어나며, sub-micron의 미세한 입자크기

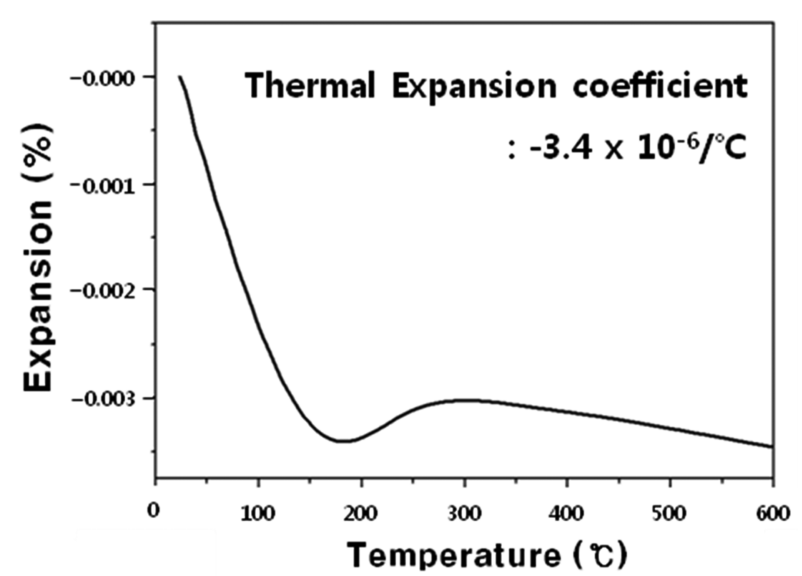

Fig. 8. Thermal expansion curve of sintered $\mathrm{Zr}_{2} \mathrm{WP}_{2} \mathrm{O}_{12}$ ceramic prepared from cold isostatic pressed green body with $3 \mathrm{wt} \% \mathrm{Al}(\mathrm{OH})_{3}$ additive.

를 보였다. 약 $1200^{\circ} \mathrm{C}$ 에서 합성이 이루어지는 $\mathrm{Zr}_{2} \mathrm{WP}_{2} \mathrm{O}_{12}$ 분말은 액상소결에 의하여 치밀화를 유도할 수 있으며, 새로이 적용된 소결조제인 $\mathrm{Al}(\mathrm{OH})_{3}$ 에 의하여 상대밀도 약 $90 \%$ 에 이르는 $\mathrm{Zr}_{2} \mathrm{WP}_{2} \mathrm{O}_{12}$ 를 $1200^{\circ} \mathrm{C}$ 에서 4 시간 열처리하 여 제조할 수 있었다. 고압의 냉간등압 성형을 거친 시편 은 약 $1 \mathrm{wt} \%$ 의 $\mathrm{Al}(\mathrm{OH})_{3}$ 첨가에 의하여 약 $85 \%$ 달하는 상대밀도 값을 보였으며, $4 \mathrm{wt} \%$ 첨가부터는 더 이상의 밀 도증가를 보이지 않았다. 일축가압 성형에 의해 상대적으 로 성형밀도가 낮은 시편의 경우는 $3 \mathrm{wt} \% \mathrm{Al}(\mathrm{OH})_{3}$ 첨가 부터 밀도의 증가를 보였다. $\mathrm{Al}_{2} \mathrm{O}_{3}$ 를 소결조제로 사용하 였을 경우는 액상의 형성이 거의 이루어지지 않아 치밀 화가 관찰되지 않았다. 새로운 소결조제인 $\mathrm{Al}(\mathrm{OH})_{3}$ 를 사 용하여 제조된 $\mathrm{Zr}_{2} \mathrm{WP}_{2} \mathrm{O}_{12}$ 소결체는 $-3.4 \times 10^{-6}{ }^{\circ} \mathrm{C}$ 의 음의 열팽창계수를 보였다.

\section{Acknowledgment}

본 논문은 중소기업청에서 지원하는 2012년도 산학연 공동기술개발사업(No. C0006662)의 연구수행으로 인한 결 과물임을 밝힙니다.

\section{REFERENCES}

1. D. G. Calas, L. Cormier, L. Galoisy, C. Jousseaume, G. Querel, and M. Newville, "In Situ Study of Nucleation of Zirconia in an $\mathrm{MgO}-\mathrm{Al}_{2} \mathrm{O}_{3}-\mathrm{SiO}_{2}$ Glass," J. Am. Ceram. Soc., 93 [2] 342-44 (2010).

2. K. H. Lee, Y. S. Kim, Y. J. Jung, T. H. Kim, J. H. Seo, and B. K. Ryu, "A Study of Sintering Behavior and Crystallization in $\mathrm{Li}_{2} \mathrm{O}-\mathrm{Al}_{2} \mathrm{O}_{3}-\mathrm{SiO}_{2}$ (LAS) Glass System by RSM," J. Kor. Ceram. Soc., 44 [8] 451-56 (2007).

3. T. Isobe, T. Umezome, Y. Kameshima, A. Nakajima, and K. Okada, "Preparation and Properties of Negative Thermal 
Expansion $\mathrm{Zr}_{2} \mathrm{WP}_{2} \mathrm{O}_{12}$ Ceramics," Mater. Res Bull., 44 [11] 2045-9 (2009).

4. S. Yilmaz and D. C. Dunand, "Finite-element Analysis of Thermal Expansion and Thermal Mismatch Stresses in a $\mathrm{Cu}-60$ vol\% $\mathrm{ZrW}_{2} \mathrm{O}_{8}$ Composite," Comp. Sci. Technol., 64 1895-98 (2004).

5. L. Sun and $\mathrm{P}$. Kwon, " $\mathrm{ZrW}_{2} \mathrm{O}_{8} / \mathrm{ZrO}_{2}$ Composites by in situ Synthesis of $\mathrm{ZrO}_{2}+\mathrm{WO}_{3}$ : Processing, Coefficient of Thermal Expansion, and Theoretical Model Prediction," Mater. Sci. Eng. A., 527 93-7 (2009).

6. X. Yang, X. Cheng, X. Yan, J. Yang, T. Fu, and J. Qiu, "Synthesis of $\mathrm{ZrO}_{2} / \mathrm{ZrW}_{2} \mathrm{O}_{8}$ Composites with Low Thermal Expansion," Comp. Sci. Technol., 67 1167-71 (2007).

7. X. Yang, J. Xu, and H. J. Li, "In Situ Synthesis of $\mathrm{ZrO}_{2} /$ $\mathrm{ZrW}_{2} \mathrm{O}_{8}$ Composites with Near-Zero Thermal Expansion," J. Am. Ceram. Soc., 90 [6] 1953-55 (2007).

8. X. Chu, R. Huang, H. Yang, Z. Wu, J. Lu, Y. Zhou, and L. Li, "The Cryogenic Thermal Expansion and Mechanical Properties of Plasma Modified $\mathrm{ZrW}_{2} \mathrm{O}_{8}$ Reinforced Epoxy," Mater. Sci. Eng. A., 528 3367-74 (2011).

9. K. Kanamori, T. Kineri, R. Fukuda, T. Kawano, and K. Nishio, "Low-temperature Sintering of $\mathrm{ZrW}_{2} \mathrm{O}_{8}-\mathrm{SiO}_{2}$ by Spark Plasma Sintering," J. Mater. Sci., 44 855-60 (2009).

10. A. Matsumoto, K. Kobayashi, T. Nishio, and K. Ozaki,
"Fabrication and Thermal Expansion of $\mathrm{Al} / \mathrm{ZrW}_{2} \mathrm{O}_{8}$ Composites by Pulse Current Sintering Process," Mater. Sci. Forum., 426-432 2279-84 (2003).

11. H. S. Kim, "A Study on Laser-Sealing Process of Lead-Free Glass Systems for OLED,” pp 26-78, Ph. D. Thesis, Soon Chun Hyang University, Asan, Korea, 2011.

12. S. M. Ha, "Development of Lead-free Glass Systems for OLED Sealing,” pp 26-78, Ph. D. Thesis, Soon Chun Hyang University, Asan, Korea, 2011.

13. J. S. O. Evans, T. A. Mary, and A. W. Sleight, "Structure of $\mathrm{Zr}_{2}\left(\mathrm{WO}_{4}\right)\left(\mathrm{PO}_{4}\right)_{2}$ from Powder X-Ray Data: Cation Ordering with No Superstructure," J. Solid State Chem., 120 101-4 (1995).

14. T. Isobe, Y. Kato, M. Mizutani, T. Ota, and K. Daimon, "Pressureless Sintering of Negative Thermal Expansion $\mathrm{ZrW}_{2} \mathrm{O}_{8} / \mathrm{Zr}_{2} \mathrm{WP}_{2} \mathrm{O}_{12}$ Composites," Mater. Lett., 62 3913-15 (2008).

15. L. L. Y. Chang, M. G. Scroger, and B. Phillips, "AlkalineEarth Tungstates: Equilibrium and Stability in the M-W-O Systems," J. Am. Ceram. Soc., 49 [7] 385-90 (1966).

16. J. L .Waring, "Phase Equilibria in the System Aluminum Oxide Tungsten Oxide," J. Am. Ceram. Soc., 48 [9] 493-94 (1965). 